\title{
Okumanın Tarihselliği ve Alımlama Estetiği ile Yeni Tarihselcilikte Anlamanın Tarihselliğinin İmkân ve Sinırliliklari
}

Atiye Gülfer GüNDOĞDu*

Historicism of Reading and Possibilities and Limitations of Understanding of Historicism in Reception Aesthetics and New Historicism

Citation/C: Gündoğdu, Atiye Gülfer, (2019). Historicism of Reading and Possibilities and Limitations of Understanding of Historicism in Reception Aesthetics and New Historicism, Milel ve Nihal, 16 (2), 351-374.

Abstract: The demand of the literary work to gain autonomous and fictional existence within the New Criticism in the first half of the twentieth century, radically breaks with the historicity in its interpretation. In the second half of the twentieth century, the Reception Aesthetics with the concept of "historicity of reader" and New Historicism with the concept of "historicity of text" and "textuality of history" stand at a meaningful point among efforts to return to historical consciousness that disappeared after the New Criticism. However, in both approaches, it is seen that the historicity of understanding literary texts predominantly shape through the only historicity of reader or only historicity of text. In this paper, it will be argued that this situation impoverishes the two-way historicity of understanding literary texts at two opposite ends. This paper also will mainly focus on the fundamental problems in the context of the tension relationship of literature with history in historicist literary theory, New Criticism, Reception Aesthetics and New Historicism. It will also be stated that reading the literary text is basically historical with its different dimensions such as the reader finds himself/herself thrown into history, the temporal of experience, the incompleteness of human existence and literary text. The ability to establish a meaningful relationship with history and historical without damaging the fictional existence and autonomy of literary text can be realized through the historicity of reading.

Keywords: History, Reading, Historicity of Understanding, Reception Aesthetics, New Historicism.

* $\quad$ Dr. Öğr. Üyesi, Ondokuz Mayıs Üniversitesi, Fen-Edebiyat Fakültesi, Türk Dili ve Edebiyatı Bölümü [atiyegulfer.kaymak@omu.edu.tr] ORCID: 0000-0002-50731288. 
Atıf/C: Gündoğdu, Atiye Gülfer, (2019). Okumanın Tarihselliği ve Alımlama Estetiği ile Yeni Tarihselcilikte Anlamanın Tarihselliğinin İmkân ve Sınırlılıkları, Milel ve Nihal, 16 (2), 351-374.

Öz: Edebi eserin yirminci yüzyılın ilk yarısında Yeni Eleştiri içerisinde otonom ve kurgusal varlık kazanma talebi, yorumlanması hususunda tarihsellikle bağını radikal biçimde koparır. Aynı yüzyılın ikinci yarısında ise "okurun tarihselliği"ne dikkat çeken Alımlama Estetiği ve "metnin tarihselliği, tarihin metinselliği" kavramlarıyla anılagelen Yeni Tarihselcilik, Yeni Eleştiri sonrası bastırılan tarihsel bilince dönüş çabaları arasında anlamlı bir noktada durur. Ancak her iki yaklaşımda da edebi metinleri anlamanın tarihselliğinin, okurun yahut metnin tarihselliği üzerinden şekillendirilmesinin ağır bastığı görülür. Bu yazıda, ortaya çıkan bu durumun, edebi metinleri anlamanın çift yönlü tarihselliğini iki karşı uçtan eksik bıraktığı iddia edilecektir. Diğer taraftan, yazı boyunca tarihselci edebiyat teorisi, Yeni Eleştiri, Alımlama Estetiği ve Yeni Tarihselcilik içinde edebiyatın tarihle kurduğu gerilimli ilişkisi konusundaki temel sorular üzerinde durulacaktır. Bu yazıda ayrıca, edebi metnin okunmasının; okurun kendisini tarih içinde buluvermesi, tecrübenin zamansallığı, insanın ve edebi metnin tamamlanamazlığı gibi boyutlarıyla tarihsel olduğu iddia edilecektir. Edebi metnin kurgusal varlığı ve otonomisini incitmeksizin tarihle, tarihsel olanla anlamlı bir ilişki kurabilmesi ancak okumanın tarihselliği üzerinden gerçekleştirilebilir.

Anahtar Kelimeler: Tarih, Okuma, Anlamanın Tarihselliği, Alımlama Estetiği, Yeni Tarihselcilik.

\section{Giriș}

Edebi metin, anlamının çok uzun bir müddet "onu üreten ve kus,atan baglama ait olarak"1 değerlendirilişinin ardından Yeni Eleştiri (New Criticism) içinde elde ettiği konumla kendisini ortaya çıkaran bağlarından azadeleşerek otonomisini ilan eder. Yeni Eleştirinin önemli isimleri Wimsatt ve Beardsley'in ünlü kavramları "niyetsel yanılg1" (intentional fallacy) ${ }^{2}$ ve "etkisel yanılg1" (affective fallacy) ${ }^{3}$ eşliğinde söylenecek olunursa, edebi metnin anlamı ve edebîliği ne metnin gerisindeki yazarın niyetinin keşfine ne de met-

1 Terry Eagleton, Edebiyat Kuramı: Giriş, çev.: Tuncay Birkan (İstanbul: Ayrıntı Yayınlar1, 2011), 58.

2 William Kurtz Wimsatt ve Monroe Curtis Beardsley, "The Intentional Fallacy", The Verbal Icon: Studies in the Meaning of Poetry, (Kentucky: University of Kentucky Press, 1954), 3-20.

3 Wimsatt ve Beardsley, "The Affective Fallacy", 21-40. 
nin okur üzerinde oluşturduğu duygusal etkiye bakarak ele alınabilir. Edebi metni anlama çabası, bu niyetsel ve etkisel yanılgıya düşmeyi önleyebilecek bir soyutlanmayı ve bir bütün olarak metnin bizatihi kendisine yönelmeyi gerekli kılarak, ilk defa metni oluşturan dilin gerisinde bulunan bir bilince yahut somut bir gerçekliğe ulaşabilmenin dışında bir anlam ifade eder.

Edebi metnin yirminci yüzyılın ilk yarısında Yeni Eleştiri içinde kazanmış olduğu özerklik şüphesiz önemli bir kırılmayı ifade eder ve bu haliyle edebi metinleri anlama/yorumlama tarihinde kolay kolay terk edilebilir bir etki oluşturmaz. Nitekim Culler'ın "Yeni eleştiri II. dünya savaşından bu yana sorgulanmış, kötülenmiş ama göz ardı edildiği pek olmamıştır." 4 şeklindeki beyanı ve her eleştirel biçimin bir biçimde Yeni Eleştirinin öne çıkardığ 1 kavramlardan (otonomi, bütünlük, yakın okuma) etkilenmek durumunda kald1ğını öne sürmesi büyük ölçüde bu durumla ilgilidir. ${ }^{5}$ Edebi metin etkisi bu denli yayılmacı ve artık geri döndürülemez bir biçimde açı̆̆a çıkan Yeni Eleştiri içinde özerklik ve kurgusal varlık talebine oldukça tatminkar bir cevap bulur. Edebi metin, tarihsel olan her şeyle bağını koparan, göndericisi, tarihi ve alıcısı olmayan bir bağlamsızlığın kıyısına sürüklenen şişe içindeki metin haline gelir. Aksoy'un ifadesiyle artık "okur ve eleştirmen için gerekli olan tek tarihi bilgi kelimelerin tarihi, şiirde kullanılan kelimelerin tarihi süreçte kazandığı anlamlar, yan anlamlar ve yarattığı çağrışım$\operatorname{lard}_{1}[\mathrm{r} .]^{\prime \prime 6}$

Diğer taraftan bu durum, edebi metnin yorumlanması hususunda tarihsel olanla bağını tamamen koparan bir husus olarak bu yorumlama biçiminin üzerinde en fazla durulan sınırlılığ lir. Gelinen bu noktadan sonra, edebi bir eserin okunması sırasında metnin iç yapısını önceleyen edebi yaklaşımlar ile metin dışı bağlamsal unsurları önemseyen yaklaşımların kutuplaştırılmasıyla, edebiyatın tarihle kurmuş olduğu ilişki gerilimli bir hal almaya baş-

4 Jonathan Culler, "Yorumun Ötesinde", çev.: Ahmet Kocaman, Kuram Dergisi 5 (1994): 62.

5 “Eleştirel bağlantılarımız ne olursa olsun hepimiz 'Yeni eleştirmen' olduğumuzu öne sürebiliriz; şu anlamda: Bu anlayış yazınsal yapıtın özerkliği kavramlarından kaçmakta ciddi bir çabayı, yapıtın bütünlüğünü göstermenin önemini ve 'yakın okuma' gereksinmesini ortaya koyar." Culler, "Yorumun Ötesinde", 62.

6 Nazan Aksoy, "Yeni Eleştiri", Eleştiri ve Eleştiri Kuramı Üstüne Söylemler, haz.: Mehmet Rifat, (İstanbul: Düzlem Yayınları, 1996), 21. 
lar ve edebiyat teorileri ve eleştiri tarihinde hatırı sayılı bir yer edinir. ${ }^{7}$ Zira bu yaklaşımların bir kısmı edebiyatın tarihle kurduğu ilişkiyi, edebi metnin anlamının ortaya çıkarılmasının zorunlu bir gerekliliği olarak görürken diğer kısmı tarihi, edebiyatın kurgusal dünyasını tahrip eden bağlam dışı bir unsur olarak değerlendirme eğilimindedir. Palmer, bu durumu edebiyat profesörlerinin genel olarak "formalist-tat uzmanı" yahut "antikacı" olarak tasnif edilebileceği gerçeği üzerinden ele alır. Buna göre ikinci kısma girenler diğerlerini tarihsel derinlikten uzaklıkla itham ederken formalist-tat uzmanları olanlar ise antikacıları metni gerçekçi bir sanat olarak görememekle suçlar. ${ }^{8}$ Tam da bu noktada bu yazıda tartışılacak ilk sorusu da ortaya çıkmış olur: Edebi metnin kurgusal varlığı ve otonomisine halel getirmeksizin tarihle, tarihsel olanla anlamlı bir ilişki kurabilmesi mümkün müdür? İki farklı uçta olmaklık bağlamında Palmer'in Amerika'daki portresini kabaca çizdiği bu halin Türk edebi düşüncesi içinde oluşturabileceği benzer sorunlara Kayalı işaret eder. Türk edebiyatının, siyaset kıskacından biçimcilik kıskacına tarihsel ve sosyolojik damarını kaybetme tehlikesi sınırında gezinişine, yazısının başlığından itibaren açık bir biçimde dile getiren Kurtuluş, tarihsel ve biçimsel olan arasındaki ilişkinin itidalden uzakta ifrat ve tefrit arasında vuku bulmaklığına dikkat çeker. Buna göre edebiyatın kurgusallığı gereğince toplum gerçeklerinden soyutlanmış bir anlayış gündeme gelmiş ve bu anlamda geçmiş dönemin edebiyat anlayışı da iyice karikatürleştirilmiştir. ${ }^{9}$

Dikkat edilirse, edebi metnin yorumlanması hususunda kayda değer bir hacim oluşturan bu tartışmalar temelde metin dışı bağlamsal bir unsur olarak tarihin edebi metnin anlamına yön verebilmesinin kabulü yahut reddiyle ilgilidir. Kuşkusuz düşüncenin bu güzergahta ilerleyişine Walter Scott'un romanları üzerinden ortaya atılan "tarihsel roman" kavramının katkısı olduğu söylenebilir. Uysal'ın öne çıkardığı gibi tarihi roman, gerçekçi roman anlayışıyla benzer

7 Edebiyatın tarihle kurduğu ilişkiyi araştıran çalışmasının sunuşunda Zeynep Uysal, Walter Benjamin'in tarih meleği benzetmesinden hareketle, tarih meleğinin belki de en çok edebiyatın omzunda durduğunu dile getirir. Edebiyatın Omzundaki Melek, Edebiyatın Tarihle İlişkisi Üzerine Yazılar, haz.: Zeynep Uysal, (İstanbul: İletişim, 2011), 7-8.

8 Richard E. Palmer, Hermenötik, çev.: İbrahim Görener, (İstanbul: Ağaç Kitapevi, 2008), 238, 320.

9 Kurtuluş Kayalı, "Siyaset Kıskacından Biçimcilik Kıskacına Tarihsel ve Sosyolo-

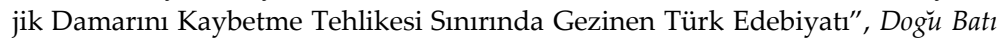
Dergisi 22 (2003): 80. 
bir biçimde kurgusal bir eser olarak romana "gerçekliğe sadakat misyonu yükler, üstelik tarihsel kayıtlar, olaylar ve kişiler söz konusu olduğu için bu sadakati belgesel boyuta taşı[r]."10 Her ne kadar zamanla tarih, postmodern tarihi romanlar içerisinde bu eserlerin kendine dönük (self-reflexive) yapısı itibarıla bağlamsal bir unsur olmaklığının dışına çıkmış olsa da ${ }^{11}$ neticede burada dahi edebi metnin anlamına yön verebilecek zamansal-mekânsal bir alan olarak konumlandırılmaya, edebiyatla ilişkisi bu minval üzere sorunsallaştırılmaya devam eder.

Geldiğimiz noktada bu yazıda tartışılması amaçlanan temel sorularımız da iyice belirginleşmeye başlar: Edebiyatın tarihle, tarihsel olan yegâne ilişkisi, tarihin edebi metnin muhtevasının kendisiyle ilişkilendirilmesi (kabul, inkâr yahut postmodern roman anlayışında olduğu gibi böyle örtüştürmenin manasızlığ 1 şeklinde) gereken zamansal-mekânsal bir alan olmaklı̆̆ üzerinden kurulabilir mi? Yahut tarihin, tarihsel olanın ve tarihsel bilincin edebi metnin anlamını açığa çıması hususundaki gerekliliği, yukarıda bahsettiğimiz bu örtüşmenin kabulü, reddi yahut manasızlığı vurgusunun ötesinde daha güçlü anlamsal kökenlere mi sahiptir?

Bu yazıda edebiyat ve tarih arasındaki ilişkinin, tarihin kendisine dönülerek edebi metnin anlaminı belirleyen zamansalmekânsal bir alan konumlandırılması üzerinden tesis edilemeyeceği öne sürülecektir. Edebi metni yorumlama/anlama sürecinin bizatihi kendisi tarihsel olduğu ve tarihsel bir bilincin varlığını gerektirdiği için tarihselliğin edebiyat açısından göz ardı edilemez bir kavram olduğu vurgulanmaya çalışılacaktır. Yirminci yüzyılın ikinci yarısinda, "okurun tarihselliği", "metnin tarihselliği/tarihin metinselliği" gibi öne sürdükleri kavramlarla edebi metnin yorumlanmasında tarih düşüncesini yeniden gündeme getiren Alımlama Estetiği ve Yeni Tarihselcilik yaklaşımları, edebiyatın tarihle kurduğu ilişkiyi, okuma tecrübesinin/anlamanın tarihselliği üzerinden ele almanın bir imkânı kılınacaktır. Edebi metnin kurgusal varlığı ve otonomisi incitilmeden tarihsel olanla anlamlı bir ilişki kurabileceği, edebi

\footnotetext{
10 Zeynep Uysal, Edebiyatın Omzundaki Melek, Edebiyatın Tarihle İlişkisi Üzerine Yazılar, 15.

11 Tarihe dönüş yapan postmodern roman ve yansıtmanın yanıltıcılığı üzerinde dikkatle duran bir çalışma için bk. Serpil Oppermann, Postmodern Tarih Kuramı: Tarihyazımı, Yeni Tarihselcilik ve Roman, (Ankara: Phoenix, 2006).
} 
metni anlamanın tarihselliği üzerinde ciddiyetle duran hermenötik düşünce içinde gösterilmeye çalışılacaktır.

Geldiğimiz nokta itibarıyla burada öncelikle, tarihi kendisine dönülebilir zamansal-mekânsal bir alan olarak konumlandırmak ve Yeni Eleştiri sonrası yeniden tarihe dönmek bağlamları kesişiminde "edebiyat ve tarihe dönüş" hususu üzerinde durmamız yerinde olabilir.

\section{Tarihe Dönmek Yahut Kendimizi Tarih İçinde Buluvermek}

Tarihe dönüş ne anlama gelir? Bu ifade, edebi bir metnin yorumlanması sırasında tarihin kendisine dönülebilen bir şey olduğunu mu ima eder? Yoksa edebiyatın Yeni Eleştiri sonrası bağlarını radikal biçimde kopardığı tarihe, tarihsel olana yeniden dönüşü mü? Ya da bir taraftan tarihe dönüş gerekliliği ifade edilirken, bir taraftan da tarihin kendisine dönülebilirliği vurgulanmaya ve uygulanmaya devam mı eder? Bu anlamıla asıl dönülen, tarihin kendisine dönülebilir bir şey olduğu düşüncesinin kendisi midir? Tarihe dönüş ifadesi, hem Yeni Eleştiri öncesi bağlamsal edebiyat anlayışını, hem de Yeni Eleştiri sonrası tarihe dönüş çabalarını birlikte ifade edebilme noktasında elverişlidir. Tarihselci edebiyat eleştirisi metnin anlamını belirlemek için tarihe dönerken, Yeni Eleştiri sonrası çeşitli yaklaşımlar, aralarındaki koparılan bağları yeniden örme çabası içinde tarihe döner. Bu noktada Oppermann, tarihyazımında dilbilimsel dönüşün öne çıkması gibi edebiyat alanında da 1980'lerden beri görülen bir tarihe dönüş hadisesine dikkat çeker. ${ }^{12}$

Diğer taraftan tarihe dönme hususunda sorulan bu sorulara verilebilecek cevaplar, tarihe dönmenin yahut tarihin dişına çıkmanın gerçekten mümkün olup olamayacağı meselesi ile yakından ilgilidir. Tarih gerçekten karşımızda duran bir nesne olarak edebi metnin anlamını belirlemek için kendisine dönebileceğimiz bir geçmiş olabilir mi? Yahut Yeni Eleştiri de olduğu gibi sırtımızı dönerek kendisinin tamamen dışına çıkabileceğimizi varsaydı̆̆ımız tecritsel bir alan? Tarihi kendisine dönebileceğimiz bir geçmiş olarak tasarlamak sahip olduğumuz tarih ve tarihsellik anlayışından izler taşır. Söz konusu tasarı, bizden bağımsız biçimde karşımızda duran ve hiçbir şekilde etkisi altında olmadığımız bir tarih anlayışını öne çıkarır. Oysa tarih, edebi metnin anlamını belirleyebilmek için kendi-

12 Oppermann, Postmodern Tarih Kuramı: Tarihyazımı, Yeni Tarihselcilik ve Roman, 15. 
sine dönüverdiğimiz bir geçmişten ziyade birer okur olarak kendimizi bir şekilde içinde buluverdiğimiz ${ }^{13}$ bir şeydir. Kendi dünyasına ve karşılaştığı edebi metnin dünyasına daima kendi içinde bulunduğu konum (zamansallık/mekânsallık) üzerinden bakmak durumunda olan okurun kendisini buluverdiği böyle bir ortam içinde, tarihin dışına yahut üstüne çıkabilmesi mümkün görünmemektedir.

Tarihe geri dönemeyiş yahut dışına çıkamayış, okurun zamansal tarihsel bir konum içinden geçmişte üretilen bir esere bakma zorunluluğu, edebiyatın tarihle, tarihsel olanla kurduğu daha ontolojik bir bağa atıfta bulunur. Eksikliği hissedilen yahut giderilmesi gereken şey edebi metin yorumunda okurun tarihe dönebilen bir süper-özne konumuna gelebilmesi değil, tarihsel olarak şekillenmişliği içinde hareket etmek durumunda kalmasıdır. Tatar'ın işaret ettiği gibi insan bilinci, yorum eylemi esnasında zaten bir şekilde tarih denen anlam geleneği içerisinde bir safha olarak buluverir kendisini ve "buluverme" olayının bizatihi kendisine tarihsellik denir. ${ }^{14}$ Okur edebi bir metni yorumlarken, geçmişte üretilen metne kendini içinde buluverdiği konumu, tarihselliği itibarıyla yaklaşmak zorundadır. Metnin anlamı belirlenirken okurun omuzlarına yüklenen rol, tarihin üstüne çıkabilen bir süper-özne olarak geçmişe dönebilmesi değil, uzakta kalanı yakınına getirme çabası içinde olmasıdır. Palmer'in dikkat çektiği üzere yorumun amacı, belli bir tarihsel uzaklığa köprü kurmaktır. ${ }^{15}$

Tarihsellik, insan varlığının zamansallığı ve mekânsallığı itibarıyla kendisini belli bir anlam geleneği içerisinde buluvermesi d1şında tecrübenin zamansallığı (geçiciliği), edebi metni yorumlama, anlama ve okumanın tamamlanamazlığ 1 gibi hususlarla da yakinen ilgilidir.

13 Burada insanın tarih içinde kendisini buluvermesi, insanın zamansallığı ve tarihselliği üzerinde genişçe duran Heidegger'in fırlatılmışlık (throwness) kavramına referansta bulunur.

14 Burhanettin Tatar, "İkinci Baskıya Giriş", Şevket Kotan, Kuran ve Tarihselcilik, (İstanbul: Beyan Yayınları, 2015), 16.

15 Palmer, Hermenötik, 322. 


\section{Tecrübenin Zamansallığı ve İnsan Varlığı ile Edebi Metnin Kesi- şen Yazgısı Olarak Tamamlanamazlık}

Dilthey insanın dünyada-var-oluşunun "tarihselliği" iddiasını tecrübenin zamansallığ1 (geçiciliği) üzerinden şekillendirir. Ona göre, tarihsellik temelde insan tecrübesinin zamansallı̆̆ının ifadesidir ve Palmer'in ifadesiyle Dilthey'ın ele aldığ 1 biçimiyle "zamansallık", kelimenin daha derinlerinde "tarihsel" anlamına gelir, ayrıca tecrübe kelimesinin kendisi başlı başına tarihsel bir özellik taşıdığı için de manidar bir kelimedir. ${ }^{16}$ İnsan tecrübesinin zamansallı̆̆ 1 , yani tarihselliği meselesini edebi metinlerin okunma tecrübesi içerisinde düşündüğümüzde ortaya çıkan tablo da oldukça manidardır. Okuma tecrübesi olarak yorum, kendi zamansallık ve mekânsallıkları içinden edebi metinle karşılaşan okurların, tarihsel buluşmalarında tekrar tekrar ortaya çıkan şeydir. Tekrar tekrar ortaya çıkan şeyin zamansal, geçici olmaklığını elden bırakarak kalıcı hale gelebilmesi mümkün görünmez. Zaten kalıcı hale gelen şey değişmezliği, tekbiçimciliği, herkes için geçerli ve tek doğru yorum olabileceği düşüncesini beraberinde getirir. Edebi metinlerin herkes için geçerli ve tek doğru yorumun olmadığını savunduğumuzda aslında yaptığımız şey onun tarihselliği üzerinde durmaktır.

Diğer taraftan Gadamer, insanın sonlu/sınırlı şimdinin sınırları/sınırlamaları olarak tarihselliği itibarıyla, kişinin kendisini daima bir durum içinde bulduğunu ve onu açıklamasının asla bütünüyle tamamlanamayacağını belirtir. ${ }^{17}$ Tatar bu durumu, insanın zamansallık ve mekânsallığının, insan varlığının kendi içindeki boşluk, eksiklik, tamamlanamazlık ve hatta uçurum sayesinde oluşmakta olan bir süreç olarak anlam kazanabileceğine işaret ederek dile getirir. "İnsan varlığı kendisindeki eksikliği, tamamlanamazlığı veya uçurumu hiçbir zaman aşamamaktadır. Bu nedenle o her zaman şimdi olduğundan daha farklı olabilme imkânını yitirmemektedir. Kısacası insan varlığının potansiyeli, her zaman onun aktüel halinden daha fazla bir alan teşkil etmektedir." 18

Bu noktada açıkça dikkat çeken şey ise, insan varlığına ilişkin olarak burada söz konusu edilen boşluk, uçurum, eksiklik, tamamlanamazlık gibi ifadelerin, edebiyat teorileri ve felsefesinde edebi

\footnotetext{
16 Palmer, Hermenötik, 321.

17 Hans-Georg Gadamer, Hakikat ve Yöntem, II, çev.: Hüsamettin Arslan ve İsmail Yavuzcan (İstanbul: Paradigma Yayınları, 2009), 55.

18 Tatar, "İkinci Baskıya Giriş", 14.
} 
metin tecrübesi hakkında sıklıkla kullanılan kelimeler oluşudur. Metin kavramı her ne kadar dokunmuş kumaş anlamına gelen text kelimesinden geliyor olsa da edebi metin bir türlü tamamlanamayan, eksik kalan, boşluk oluşturan dokusuyla gelecekte her zaman farklı türlü açığa çıkabilme potansiyelini barındırır. Okurun edebi metne her zaman içerisinde bulunduğu zamansallık-mekânsallık içerisinden bakma durumunda kalması dişında, edebi metnin kelimelerinin belirlenemeyen ve çok katmanlı dokunmuşluğu da onu anlama ufkunun sınırlılığını oluşturan bir boyut haline gelir. Edebi metinle karşılaşan okur hem kendi tarihselliği hem de edebi metnin tamamlanamazlı̆̆ itibarıyla sonu gelmez bir yorumlama alanı içerisindedir. Sahip oldukları potansiyel ile okur ve metin, her zaman aktüel halinden fazla olmak durumundadır. Tamamlanamazlık bu anlamda hem insan varlığının hem de edebi metnin tarihselliğinin yolları bir şekilde kesişen yazgıları haline gelir.

\section{Edebi Metnin Yorumlanmasında Tarihsel Bilince Duyulan İhtiyaç}

Yeni Eleştirinin daha önce Culler'a atıfla bahsettiğimiz etkisi ve hegemonyası itibarıyla edebiyatın, edebi tecrübenin temelde tarihsel olduğu söylemek uzun süre çekinilen bir hal alır. Ancak zamanla edebi metnin yorumlanmasında tarihsel bir bilince duyulan ihtiyaç açığa çıkar. Gerçi edebi metin Yeni Eleştiri içinde kazandığı kurgusal varlık ve otonomi ile yeterince ayrıcalıklı bir konum elde etmeyi başarır. Lakin bu sefer de, anlamı bir anda tamamen ortaya çıkarılabilecek bir nesneye dönüşmesi itibarıyla edebi varlığını yeniden kaybetme tehlikesiyle karşı karşıya kalır. Bu durum, edebi metni okumanın ele almaya çalıştığımız tarihselliği ile açık biçimde çelişir. Dolayısıyla Yeni Eleştiri sonrası edebiyat ile tarihsel olan arasında kurulacak bağ, oluşabilecek çeşitli sorunları bir arada düşünmek durumundadir. Edebiyat metni ve tarih arasinda kurulacak yeni bağların edebiyat teorisi ve felsefe içinde kendilerine anlamlı bir yer açabilmeleri aynı anda hem edebi metnin otonomisine hem okumanın tek seferde ve bütünüyle tamamlanamazlığına zarar vermeme ile yakinen ilişkili bir hal alır. Bu bir anlamda tarihin geleneksel kavranış biçiminin dışında kalabilmeyi, klasik tarih tanımı ve tarihsellik anlayışının bir eleştirisini de yapabilmeyi gerekli kılar.

Yirminci yüzyılın ikinci yarısında, Niyetselcilik, Alımlama Estetiği ve Yeni Tarihselcilik, tarihsel olanla bir şekilde bağ kurmaya çalışan yaklaşımlar olarak dikkat çeker. Bunlardan yazarın niyetini 
metni anlamanin kriteri olarak kabul eden, Hirsch ve Betti'nin önemli savunucuları olduğu niyetselciliğin yaygın tarih ve tarihsellik düşüncesinin pek de dışına çıkamadığı görülür. Niyetselcilerin öne çıkardığı metin ile anlama arasındaki ilişki, tarihi kendisine dönülebilen bir geçmiş olarak görme hususunda tarihselci edebiyat teorisi üzerine konuşurken değindiğimiz sorunlara sahiptir. Bu anlamda niyetselcilerin yirminci yüzyılın ikinci yarısında döndükleri şey tarih değil, tarihin kendisine dönülebilir olduğu düşüncesinin izleridir. Konu üzerine yazdığı doktora tezinde Tatar niyetselcilerin bu tavrını, okurun kendi ufkunu aşmak suretiyle anlamın ortaya çıktığı ana geri giderek, başkasının ufkunu, geçmiş tarihi yeniden kurmasının gerçekten mümkün olup olmadığı ve bunu yaparken de aslında anlamı, onun söylendiği anla sınırlandırma durumunda kalıp kalmayacağ ${ }^{19}$ soruları etrafında ele alır.

Alımlama Estetiği ve Yeni Tarihselcilik ise kanaatimizce niyetselcilerden daha farklı olarak yaygın tarih ve tarihsellik düşüncesinin de güçlü birer eleştirisi olmaları nedeniyle edebiyat, tarih ve tarihsellik arasında üzerinde durulmaya değer yeni bir bağ kurma gayretindedir.

\section{Tarihsellikle Bağ Kurma Çabası Olarak Alımlama Estetiği ve Yeni Tarihselcilik}

Gadamer'in felsefi hermenötiğinden etkilenen, "okurun ve okumanın tarihselliği" ni ön plana çıkaran Hans Robert Jauss'un Alımlama Estetiği (rezeptionsasthetik) ile sahip oldukları yaklaşımları Louis Montrose tarafından "metnin tarihselliği" ve "tarihin metinselliği" kavramları eşliğinde dillendirilen Yeni Tarihselcilik, yirminci yüzyılın ikinci yarısında, edebiyatın tarihsel olanla bağını yeniden gündeme getirir.

$\mathrm{Bu}$ iki yaklaşım hangi noktalarda geleneksel tarih, tarihselcilik düşüncesinin dışına çıkmayı başarır? Yazı boyunca ele almaya çalışılan kendini tarih içerisinde buluverme, tamamlanamazlık, tecrübenin zamansallığı gibi noktalarda okurun, metnin, okuma tecrübesinin toplamında edebiyatın tarihselliği hususunda bize ne söyler? Edebi bir metni okuma, anlama, yorumlamanın tarihselliğinin daha önce dile getirdiğimiz gereklilikleriyle uyumlular mı? Dahası yazının başından itibaren sorunsallaştırıldığı gibi tarihsel olanla anlamlı

19 Burhanettin Tatar, Felsefî Hermenötik ve Yazarın Niyeti: Gadamer vs. Hirsch (İstanbul: Vadi Yayınları, 2016), 25. 
bir ilişki kurarken metnin otonomisini de aynı zamanda korumayı sürdürebilirler mi?

Öncelikle, her iki yaklaşımın kendilerini sırasıyla biçimci yöntemler, Marksizm (Alımlama Estetiği) ve Yeni Eleştiri, Marksizm'in bazı boyutlarına (Yeni Tarihselcilik) bir itiraz olarak sunması, onların bir taraftan tarihsel olanla yeni bir ilişki kurma ve Marksizm'in katı estetiği dışına çıkma istek ve niyetlerinin açık bir göstergesidir. Tarihsel olarak açığa çıkışları itibarıyla, bu iki yaklaşım üzerinde ayrı ayrı durmak, yukarıda bahsedilen sorunlara daha yoğun odaklanabilme imkânı sağlayacaktır.

\section{Alımlama Estetiğinde Anlamanın Tarihselliği}

Okur merkezli teorilerle neredeyse eş anlamda kullanılan "alımlama" kelimesine bünyesinde ilk defa yer açan ve bunun estetikle olan bağlarını kurmaya çalışan "alımlama estetiği"nin (Rezeptionsasthetik) tarihsellikle güçlü bir bağ kurduğunu söylemek belki başlangıçta şaşırtıcı gelebilir. Alımlama estetiği adlandırması, tarihle edebiyat arasında kurmuş olduğu bağı ve bu noktada sahip konumu, Yeni Tarihselcilik adlandırmasında olduğu kadar açık bir biçimde yansıtmayabilir.

Ancak gelin görün ki, Hans Robert Jauss, alımlama estetiğini tarih/edebiyat ilişkinin iki temel boyutu olan tarihsel bağlamın edebi eserin yorumlanmasına etkisi ve edebiyat tarihi yazımı üzerine kurar. Okurun edebî metinleri alımlamasına dayanan yeni bir edebiyat tarihi yazımı önerisiyle şekillendirdiği alımlama estetiği teorisiyle Hans Robert Jauss, bu iki temel boyutu bir anlamda kaynaştırır. Alımlama estetiği edebiyat perspektifinde tarihe açmış olduğu bu çok boyutlu yer itibarıyla, edebiyat eseri, yorum, anlama, tarih, tarihsellik, edebiyat tarihi gibi konu ve kavramlar üzerine düşünmenin de zengin bir imkânı haline gelir.

Paul Ricoeur'un, Jauss'un fenomenolojik bir okuma edimi oluşturmaktan ziyade, edebiyat tarihi yazımını yenilemeye yöneldiğini vurgulamas $1^{20}$ onun okuma teorisinde tarihe açmış olduğu bu geniş yer itibarıyladır. Yine Jauss ile birlikte Konstanz ekolünün ikinci önemli ismi olan Wolfgang Iser'ın estetik tepki teorisini (wirkungstheorie) Jauss'un alımlama estetiğinden ayırırken “bir alımlama teo-

20 Paul Ricoeur, Zaman ve Anlatı: Dört, Anlatılan (Öykülenen) Zaman, çev.: Umut Öksüzan ve Atakan Altınörs (İstanbul: Yapı Kredi Yayınları, 2013), 289. 
risi okurun tarihsel yargılarına sıkı sıkıya bağlıyken, bir tepki teorisinin köklerinin tamamen metnin içinde yer aldığııı" ${ }^{21}$ belirtmesinin altında Jauss'un tarihsel olanla kurmuş olduğu önemli bağ vardır. Ayrıca, Iser'ın metnin kendisinden pek de hareket edemediği eleştirisi, ilerleyen paragraflarda Jauss'un metnin tarihselliğini ihmali hususunda kendisine yeniden dönülecek bir husus olacaktır.

Jauss'un Konstanz Üniversitesi açılış konuşmasında sunmuş olduğu "Literary History as a Challenge to Literary Theory" 22 adlı metin, onun alımlama estetiğinin sınırlarını kabaca çizdiği ve diğer düşüncelerini üzerine inşa ettiği bir temel olma özelliği taşır. Metin, Marksist ve biçimci yöntemler arasında sıkışıp kalarak edebiyatın ya salt tarihsel ya da estetik boyutunu önceleyen edebiyat tarihi yazımının hâlihazırda sahip olduğu sorunlar üzerinde durur. Edebiyat tarihinin, edebiyatın estetik ve tarihsel boyutu arasında oluşturulan bu uçurumu ortadan kaldıracak biçimde yeniden yapıland1rılması gerekliliğine işaret eder. Uçurumu ortadan kaldıracak şey hem tarihsel hem de estetik açıdan vazgeçilmez bir öneme sahip olan okurdur.

$\mathrm{Bu}$ anlamda Jauss metnin yazarının psikolojisi ve biyografisi üzerine temellenen, yazarın psikolojik şartlarını tekrar yaşamayı hedefleyen yahut edebî bir eseri üretim ve canlandırma estetiğinin kapalı döngüsü içinde ele alan edebiyat tarihi anlayışını yenilemeyi amaçlar. Edebiyatın alımlanması (rezeption) ve etki (wirkung) boyutunu o zamana kadar budadığını düşündüğü edebiyat tarihçiliğine, yazısının başlığında da görüldüğü üzere bir çağrıda bulunarak "okurun edebî metinleri alımlamasına dayanan yeni bir edebiyat tarihi modeli"ni önerir. Buna göre her edebî eserin anlamı, tarih içinde

21 Wolfgang Iser, "Preface", The Act of Reading: A Theory of Aesthetic Response (Baltimore, London: John Hopkins University Press, 1978), x.

22 Orijinal adı, Hans Robert Jauss, Literaturgeschichte als Provokation der Literaturwissenschaft, Konstanzer Universitätsreden 3, Konstanz 1967. "Literaturgeschichte als Provokation der Literaturwissenschaft", Literaturgeschichte als Provokation, Frankfurt 1970, 144-207. İngilizce çevirisi, Hans Robert Jauss, "Literary History as a Challenge to Literary Theory", Toward on an Aesthetic of Reception, trans.: Timothy Bahti (Minneapolis: The University of Minnesota Press, 1982), 3-45. Makale Türkçeye, 1980 yılında Tevfik Turan tarafından çevrilir. Hans Robert Jauss, “Bilimsel Bir Yazın Tarihinin Çağırışı", çev.: Tevfik Turan, Bă̆lam Dergisi 2 (İstanbul 1980): 89-122. Bu çalışmada genel itibarıyla Turan'ın çevirisi kullanılmış olup, bu makalenin sahip olduğu dille bir bütünlük ve tutarlılık oluşturabilme adına bazı kelimelerin eş anlamlıları kullanılmak durumunda kalınmıştır. 
okurların kendilerini alımlarken gösterdikleri tepkilere göre değerlendirilir ve değişkenlik gösterir. Edebî metin bir defada ve bütünüyle ortaya konabilecek nesnel bir anlama sahip değildir.

Okurun ancak kendi tarihselliği içinden metni anlama geleneğine katkıda bulunabileceğini, edebiyat tarihinin de okurların anlama geleneğine yaptıkları bu katkılarının toplamı şeklinde oluşması gerektiğini ifade eden Jauss'un önerdiği bu yeni edebiyat tarihinin, okurun ve okumanın tarihselliği noktasında önemli bir vurguya sahip olduğu görülür. Bunda Jauss'un, insanın ve anlamanın tarihselliğini ciddiye alan Alman filozof Gadamer'in felsefi hermenötiğini edebiyat teorilerine taşıma çabası içinde oluşunun önemli bir rolü vardır. Gadamer de Jauss'un bu çabası üzerinde durur, felsefi hermenötiğin "ön anlama" kavramı ve "etki tarihi" ilkesinin merkezcil motiflerinin farklı alanlara tesir ettiğini, ve sorunlu gördüğü bazı hususlara rağmen bu tesiri edebiyat teorisi alanında "alımlama estetiği" ile Jauss'un temsil ettiğini belirtir. ${ }^{23}$

Gerçekten de alımlama estetiğinde yer alan "beklenti ufku, ön anlama, etkiler tarihi, soru ve cevap diyalektiği", gibi kavramlar itibarıyla onun, doğrudan yahut dolaylı olarak anlam ve tarihsellik arasında ilişkiyi önemsediğini görürüz. Alımlama estetiğinde okur, edebi bir metin karşısında ön anlamalarıyla sahip olduğu bir beklenti ufkuna sahiptir. Bu anlamda her okur kendisini, ön anlamaları ile (tarih denen) anlama geleneğinin bir safhası olarak tarih içinde buluverir. Beklenti ufkunu ise, o günkü ve ileriki okurların edebi tecrübeleri oluşturur. Estetik ve tarihsel fark edişleriyle okur bir taraftan, edebi metnin estetik değerini o zamana kadar okumuş olduğu eserlerle karşılaştırarak değerlendirir, bir taraftan da kendi şekillenmiş tarihselliği içinden onu anlama geleneğine katılarak, bir alımlamalar zincirinin parçası haline gelir. Böylece metnin hem tarihsel önemini belirler ve hem de estetik değerini görünür kılar. Beklenti ufkunun okurun okuma tecrübelerine bağlı olarak sürekli bir değişim, dönüşüm, yeniden kurulma hadisesi içinde olması onun tarihselliğini ifade eder. Edebi metin, içinde durmadan yalın izlemenin eleştirici anlamaya, pasif alımlamanın aktif alımlamaya, yerleşmiş estetik kuralların bunları aşan yeni ürünlere dönüştürüldüğü bir akışın hep değişen tecrübeler ufku içindedir. ${ }^{24}$

\footnotetext{
23 Hans-Georg Gadamer, "Hermeneutik”, Hermeneutik Üzerine Yazılar, der. ve çev.: Doğan Özlem (İstanbul: İnkılap, 2003), 24.

24 Jauss, "Bilimsel Bir Yazın Tarihinin Çağırışı", 90.
} 
Alımlama estetiği ayrıca, etki tarihiyle ilgili olarak göz önünde bulundurduğu metinle okur arasındaki soru ve yanıtlardan oluşan diyalog yaklaşımını benimser. Geçmişte üretilen bir edebi metin, ancak bugünün okuru onu gerilerde kalmışlığından koparıp günümüze getirecek olan soruyu sorduğunda ona cevap verip, bir şeyler söyleyebilir. Bu okurların içinde bulunduğu zamana göre onu şimdiye getirecek soru ve cevabın değişebileceğine, bu anlamda okuma tecrübelerinin zamansallığına yapılan bir vurgudur. Bu durumda okur kendisini fırlatılmış olarak buluverdiği tarih içinden sorusunu yöneltebilir ve okurun metni gerilerde kalmışlığından koparıp günümüze getiren sorusu uzakta olanı yakına getirme görevini üstlenir.

Jauss ayrıca, klasik tarih ve tarihselcilik düşüncesine birçok açıdan eleştirel biçimde yaklaşır. Bu husustaki dikkatlere yer verildiğinde onun, edebi metnin anlamlandırılması noktasında "tarih üstü yahut tarih dışı' olmaklığa mesafeli yaklaşımıyla karşılaşırız. Söz gelimi Jauss, az evvelce değinilen metnin okur aracılığıyla geçmişte kalmışlı̆̆ından kurtarılarak bugüne getirilme hadisesini, tarihselciliğin kesmiş olduğu bağların yeniden düğümlenmesi olarak değerlendirir: "Edebiyat tarihi böyle, metinle okur arasında yer alan ve süreklilik gösteren bir diyalog içinde ele alınırsa, o zaman edebiyatın estetik ve tarihsel yönleri arasındaki karşıtlık da sürekli olarak kapatılmış, böylece aynı zamana geçmiş edebiyattan bugüne kalan izle bugünün edebi tecrübesi arasında olması gereken, ama tarihselciliğin kesmiş olduğu bağlar yeniden düğümlenmiş olur." 25

Jauss'un burada eleştirdiği, edebi metnin anlamının tarihe dönülerek ve bir seferde elde edilebileceğini ileri süren klasik tarihselciliktir. Jauss'a göre ise tarih, edebi metnin anlamının belirlenmesi için kendisine dönülen bir geçmiş değil uzakta olanı yakına getirme çabasının okurla metnin farklı zamansal buluşmalarında açı̆̆a çıktığı bir anlama zeminidir. Jauss benzer bağlamda nesnel tarih anlayışını da eleştirir. Ona göre, gerilerde kalmış bir zamanın olaylarını "nesnel" biçimde betimlemek anlamına gelen bu tarih anlayışı, edebiyatın hem sanat niteliğine hem de kendine özgü tarihselliğine aykırı düşer. Bu anlamda, R. G. Collingwood'un, nesnelci tarih görüşünü eleştirirken kullandığ 1 "Tarih, geçmişin tarihçinin zihninde yeniden devinim kazanmasından başka bir şey değildir" , önermesinin edebiyat tarihi için daha da geniş ölçüde geçerli olduğunu belirtir.

25 Jauss, "Bilimsel Bir Yazın Tarihinin Çağırışı”, 90. 
Edebi eser, her zaman her okura aynı biçimde gözükecek bir nesne değil, daha çok okuyanların hep kendisine yeniden ses verdiği bir nota gibidir. Jauss'un çizmiş olduğu bu tarih perspektifinin okuma tecrübesinin zamansallığına, anlamanın tarihselliğine yapmış olduğu atıf açıktır. Okur ait olduğu zamansallık ve mekânsallık içinden edebi metinlerle buluşup ona ses verir. Jauss ayrıca, edebiyatla tarih, estetik bilgiyle tarihsel bilgi arasındaki uçurumun kapanabilmesi için, edebiyat tarihinin, "genel tarihin akışını edebi metinlere yansıyan biçimiyle bir kez daha betimleyip geçme"nin ötesine geçmesi gerektiğini ${ }^{26}$ söyleyerek bağlamsal tarih eleştirisine karşı mesafesini de ortaya koyar. Ancak diğer taraftan, tarihin tamamen d1şında kalınabileceği düşüncesinin mümkün olmayışının da altını çizer. Edebi metnin anlamının zamandan bağımsız bir biçimde, yalnızca metnin içine dalınarak görünebileceği düşüncesinin uzağındadır. Tarihyazımında anlamlı bir yere varılmak isteniyorsa tarihin dışına çıkılabileceğini öne süren tarih dışı kimlik, bir kenara sıyrılmalıdır. ${ }^{27}$

Ayrıca tarih ile okur arasında kurduğu ilişkide Jauss, sadece içinde bulunduğu zaman ve mekânsallık itibarılyla salt biçimde tarihe bağımlı olmak durumunda kalan bir okura yer vermez. Gadamer'in "tarihsel olarak etkilenmiş bilinç" kavramının da etkisiyle alımlama estetiğinde okur, bir taraftan tarih tarafından biçimlendirilmiştir ancak bir taraftan tarihe yön verebilen bir enerjiye de sahiptir: "Yazar, eser, okur üçgeninin son köşesi yalnızca edilgen olan öğe, salt tepkilerden oluşan bir zincir değil, yeniden tarih yaratıcı nitelikte bir enerjidir. Yazın yapıtının tarih içindeki yaşamı okurunun etkin payı olmadan düşünülemez." 28 Okur sadece mevcut ortama bağımlılığı itibarıyla tepki veren değil, aynı zamanda aktif, yaratıcı nitelikteki bir enerji halinde, tarihsel olarak etkilenmiş bilince sahiptir. Zira Tatar'ın işaret ettiği gibi, tarihsel olarak etkilenen bilinç, sadece bilincin geçmişin etkisi altında bulunduğu anlamına gelmez; ayrıca o, bu etki hakkındaki bilinçlilik durumuna da işaret eder. ${ }^{29}$

Diğer taraftan Jauss, okurun tarihe yön verebilmesini sağlayacak güç olarak gördüğü, okurun metni biçimlendirmesi hususuna

\footnotetext{
26 Jauss, "Bilimsel Bir Yazın Tarihinin Çağırışı", 113.

27 Jauss, "Bilimsel Bir Yazın Tarihinin Çağırışı", 113.

28 Jauss, "Bilimsel Bir Yazın Tarihinin Çağırışı", 90.

29 Burhanettin Tatar, 3 Derste Hermenötik (İstanbul: Vadi Yayınları, 2016), 109.
} 
abartılı bir vurgu yapar. Elbette bu onun, "edebi metnin tek doğru yorumu olduğu" anlayışını yıkmak için okurun alımlamaları ve tarihselliğini ön plana çıkarma arzusuyla yakinen ilgilidir. Ancak bu durum Jauss'un, okurun ve okumanın tarihselliğinin altını çizerken, edebi metnin varlığının okumanın tarihselliğine etki eden boyutunu ihmal etmesine neden olur. Oysaki okur kadar edebi metin de var oluş tarzı, tecrübe ediliş biçimi itibarıyla okumanın tarihselliğine katkıda bulunan bir kavramdır. Jauss'un alımlama estetiğinde ise metin, daha önce de değinildiği üzere tek başına var olamayan, ancak kendisini okuyanların hep yeniden ses vermeleriyle ayakta duran bir nota konumundadır. Kendi başına var olamayan metnin okuma tecrübesinde okurunu yönlendiren, biçimlendiren tabiatı gerilerde kalır. Oysaki edebi metin eksikliği, tamamlanamazlığı itibarryla gelecekte şimdi olduğundan daha farklı olabilme potansiyeline sahiptir. Bu noktada kanaatimizce alımlama estetiğinin sorunu, okurun tarihselliği itibarıyla edebi metni sonsuz biçimlendirme imkânını ön plana çıkarırken, metnin tamamlanamazlığı, belirlenemezliği noktasındaki tarihselliğini eksik bırakmasıdır. Alımlama estetiği okumanın ve okurun tarihselliği üzerinden edebiyat ve tarihsellik arasında bir ilişki kurarken belki metnin otonomisine ve kurgusal varlık talebine zarar vermez ama okurdan bağımsız kendi başına bir dünyası olduğunu göz ardı ettiği metnin varlığını da büyük bir hasara uğratır.

\section{Yeni Tarihselcilikte Anlamanın Tarihselliği}

Yeni Tarihselciliğin alışıldık tarih ve tarihselcilik düşüncesi ile bir hesaplaşma içinde olduğu, alımlama estetiğinden farklı olarak daha başlığından itibaren kendini hissettirir. Edebiyat ile tarihyazımı arasında iç içe geçmiş ilişkiler ağını sorunsallaştıran bu yaklaşım, Oppermann'ın öne çıkardığı üzere tarihyazımındaki dilbilimsel dönüş (linguistic turn) ile edebiyat alanında 1980'lerden beri görülen tarihe dönüşü (historic tur) bir arada tartışmaya açması anlamında dikkat çekici bir konuma sahiptir. Ancak burada yazımız itibarıyla önemli olan sorun, Stephen Greenblatt, Catherine Gallagher, Louis Montrose gibi öne çıkan bazı isimlere sahip olan bu yaklaşımın 1980'lerde yeniden tarihe dönüşü değil, sahip olduğu kavramsal birikim ve düşünme biçimi açısından tarihin kendisine dönülebilir bir şey olup olmadığ1 konusunda nerede duruyor oluşudur. Yeni Tarihselciliğin tarihyazımı ve edebiyat arasındaki ilişkiler ağını çift yönlü olarak ele alışı, Louis Montrose'un ünlü “metnin tarihselliği ve tarihin me- 
tinselliği" adlandırmasında kendisini somutlaştırır. Yeni Tarihselcilik, bu bakışımlı ifade başta olmak üzere "olasılıklar tarihi, toplumsal enerjinin dolaşımı, anekdotlar, yoğun betimleme, edebi metnin ayrıcalıklı konumunu yitirmesi" gibi sahip olduğu kelime ve konu dünyası itibarıyla, edebi metni anlamanın, edebi tecrübenin tarihselliği noktasında bizlere neler söyler?

Yeni Tarihselcilik Catherine Gallagher ve Stephen Greenblatt'ın kendi ifadeleriyle ilk elden, "Amerikan Yeni Eleştirisine tahammül edememek, kurulu kuralları ve yordamları tedirgin etmek, uyuşmaz ve huzursuz bir merakın karışımı anlamına" ${ }^{30}$ gelir. Yine, Yeni Eleştiri haricinde başlangıçta içinde piştikleri Marksist teorilerin üstyapı ve altyapı veya ezilen sınıf bilinci gibi anahtar kavramlarından rahatsız oldukları için kendilerini "ideoloji eleştirisi fikrinden söylem analizine kaymış" ${ }^{31}$ olarak bulduklarını ifade ederler. Aynı boyutlarda olmasa da Yeni Eleştiri ve bazı noktalarda Marksist eleştirinin sınırlılıklarının ötesine uzanmak isteyen çıkış noktaları itibaryyla alımlama estetiği ile belli bir benzerlik içerisinde oldukları söylenebilir. Elbette burada Yeni Eleştiri karşısında kullanılan tahammül edememek deyimi, Yeni Tarihselciliği alımlama estetiğine nazaran çok daha aşırı bir koordinata yerleştirir. Yeni Tarihselcilik her ne kadar, yoğun betimleme (thick description) ${ }^{32}$ kavramı ve Ezra Pound'un bir yazısından hareketle giriştikleri "Işıldayan Detay Yöntemi" 33 ile Yeni Eleştirinin "yakın okuma" kavramını hatırlatsa da, bu iki okuma tarzı arasındaki farka özellikle dikkat çekmek ister gibidir: "Yakın okumalar deha övgüsüyle bağlantılı olarak yoğun bir şaşırtıcı hayranlık duygusu inşa etmeye yönelirken, Yeni tarihselci okumalar genellikle, şüpheli, ihtiyatlı gizemden arındırıcı, eleştirel hatta muhaliftir." 34

Gerçekten de Yeni Tarihselcilik "metnin tarihselliği ve tarihin metinselliği" kavramlarıyla, Yeni Eleştirinin edebi metni anlamlandırma çabasında metnin tek başına yeterli olacağı ve metnin anlamının nesnel bir biçimde ortaya konulabileceği iddialarına karşı bir

30 Catherine Gallagher ve Stephen Greenblatt, "Yeni Tarihselciliği Uygulamak", çev.: Berat Açıl, Kritik Dergisi 1 (Mart, 2008): 21. Bu çalışmada Açl'ın çevirisi kullanılmıştır.

31 Gallagher ve Greenblatt, "Yeni Tarihselciliği Uygulamak", 27.

32 Gallagher ve Greenblatt, Practicing New Historicism (Chicago: The University of Chicago Press, 2000), 20.

33 Gallagher ve Greenblatt, "Yeni Tarihselciliği Uygulamak", 31.

34 Gallagher ve Greenblatt, "Yeni Tarihselciliği Uygulamak", 27. 
oluşum içindedir. "Metnin tarihselliği" bu anlamda kabaca, metnin yorumlanmasında tarihsel bağlamın önemine dikkat çeker. Kendi zaman ve mekânımıza daldırılmışlığımız, fırlatılmışlığımız itibarıyla metnin tarihselliğine tam olarak ulaşabilmek mümkün olmayacaktır. Ancak bu edebi metnin belli bir tarihselliği, toplumsallığ olmadığını söyleme meşruiyeti de vermez. Karşı uçtan göz ardı edilemecek şey ise "tarihin metinselliği"dir. Bu ifade temelde tarihin dilsel, anlatısal bir eylem oluşuna dikkat çeker ve dilsel olanın tarihi olanı aktarmada eksik bırakma, boşluk oluşturma zorunluluğunu ifade eder. Bu noktada tarih yazıcının öznel konumuna dikkat çekilir. Tarihin metinselleşmesi onun birden çok yorum ve anlamlara açılması anlamına gelir. Bu yüzden ortada tarih değil tarihler vardır ya da bir "olasılıklar tarihi." 35 Ancak diğer taraftan, geçmişin kendisini değil ama "iz"lerini bize ulaştırabilecek şey yine metinlerdir. Bu noktada metnin diğer metinler arasındaki konumu ve bu metinler arasındaki etkileşimler de üzerinde durulması gereken hususlardır. Metin sadece tarih içinde değil, diğer metinler arasında da değerlendirilmelidir. Dahası bu diğer metinler sadece tarihsel metinler olmak zorunda da değildir. Bir tapu kaydı, bir seyahatname, bir roman, bir ceza ve mahkeme tutanağı arasında hiçbir fark kalmaz. Yeni Tarihselciliğin en sorunlu noktası da kanaatimizce burada ortada çıkar. Yeni Tarihselcilik edebi eserin ayrıcalıklı konumunu ortadan kaldırarak tarih ve tarihselcilik hakkındaki bütün yeniliğine ve eleştirel duruşuna rağmen tarih-edebiyat ilişkisinin kadim probleminden kaçamaz. Edebi tecrübeyi göz ardı edişi edebi eserin otonomisini ve kurgusal varlık talebini rencide eder. Dahası bu rencide ediş en çok, tarihin metinselliği üzerine kurmuş oldukları yaklaşımlarına zarar verir. Edebi metnin şeyleştirilmesiyle ortada tarihi kendilerine benzetecekleri bir metinsellik (edebi metin) kavramı kalmaz. Kurgusallığı, tahayyül gününü kışkırtan ve bir anda tüketilemeyen tabiatı ile anlamanın zamansallığının en güçlü tezahürlerinden olan edebi metin kavramını diğer metinlerle eş seviyeye çekmek belki de en çok Yeni Tarihselcilerin kendisine zarar verir. Şiir ortadan kalkınca, "şiir kadar belirsiz tarih" benzetmesi de ortadan kalkar.

Bu sınırlılığı yanında Yeni Tarihselcilik, edebi metnin yorumlanması hususunda edebiyat teorileri içinde eksikliği hissedilen ta-

35 Gallagher ve Greenblatt, "Yeni Tarihselciliği Uygulamak”, 32. 
rihsel bilince yeterince yer açmayı başarır. Bir taraftan metnin tarihselliği üzerine uzun uzun durur ancak onu bugünün okurlarının üstüne çıkılarak kendisine dönebileceği bir sıfır noktası olarak konumlandırmaz, bu anlamda metnin tarihselliğine hiçbir zaman tam olarak ulaşılamayacağının da altını çizer. Gecikli'nin öne çıkardığ üzere, Greenblatt sözcülüğünde Yeni tarihselcilik, geleneksel tarihselciliğin zamanlar üstü, mükemmel insan modeline ulaşmak isteyişinin geçerliliğini kaybettiğini vurgular. ${ }^{36}$ Geçerliliğini kaybeden mükemmel insan (süperözne) yerini belli bir zamansallık, mekânsallık içerisinde hareket etmek durumunda kalan insana bırakır. Bu insan "en başta kendi zaman ve mekânına daldırılmış" 37 olarak bulur kendisini ve estetik tecrübe, kendisini daldırılmış olarak bulduğu zaman ve mekândan bir ölçüde "çekip çıkarılmış" 38[11ğını] ifade eder. Yine de tarihsel bir varlık olarak insan, bu estetik tecrübeyi kendini daldırılmış olarak bulduğu konum içerisinden gerçekleştirmek durumunda kalır. Şimdiden tamamen kurtulup geçmiş olayların içine girmesi söz konusu değildir. Bu noktada Gallagher ve Greenblatt'ın şu cümleleri dikkat çekicidir:

“Tarihsel olarak konumlanmış hasret, korku, endişe ve rüyalarımızın tümünü dünya hakkında birikmiş bilgimizle beraber basitçe erteleyebileceğimizi ve diğer bir kavramsal evrene girebileceğimizi hiçbir zaman hissetmedik. (...) güçlü bir şekilde bize ulaşan bir metinle karşılaştığımızda, ilkin kendi dünyamızdan çıkarıldığımızı ve daha da güçlü bir şekilde onun içine itildiğimizi hissederiz." 39

$\mathrm{Bu}$ ifadelerde de açıkça görüldüğü gibi Yeni tarihselci okumalarda okur olarak insanın tarihsel olarak konumlanmışlı̆̆ından sıyrılması, yine okurun bir çeşit ön anlamaları olarak görülebilecek dünya hakkında birikmiş bilgilerini tamamen askıya alarak geçmişte kalmış bir dünyaya boşlukta duran biri olarak girebilmesi söz konusu değildir. Alıntıdaki "bize ulaşan bir metin” ifadesine ayrıca dikkat çekmek yerinde olabilir. Bu ifade, okurun geçmişte kalan metnin dünyasına nasıl katılabileceği sorusuna bir cevap sunabilme olană̆1 taşır. Yeni Tarihselcilikte, geçmişin metinleri (birer geçmiş olarak her edebi metin) belli bir zaman aralığından diğerine geçme için yol bulmak arzusuyla özel bir konum talep ederler. Onların

36 Kubilay Gecikli, "Yeni Tarihselcilik”, Çă̆daş Edebiyatın Kuramsal Seyri, ed.: Aytaç Ören, Mümin Hakkıŏlu (Konya: Çizgi Kitabevi, 2019), 257.

7 Gallagher ve Greenblatt, "Yeni Tarihselciliği Uygulamak", 33.

Gallagher ve Greenblatt, "Yeni Tarihselciliği Uygulamak", 33.

Gallagher ve Greenblatt, "Yeni Tarihselciliği Uygulamak", 33. 
şimdiye ulaşma talebidir bu, zamansal uzaklığı aşma, uzağı yakınlaştırma talebi. İşte bu noktada Yeni Tarihselciliğin anekdota dayalı tarih anlatımının devreye girdiği söylenebilir. Anekdot anlatımı, geçmişte kalan metin ile okur arasındaki zamansal uzaklığı ortadan kaldırma noktasında önemli bir tesire sahiptir. Bu etkisiyle anekdotların, okurun uzakta olan ve elbette bütünüyle hiçbir zaman ulaş1lamayacak olanı yakına getirmesinde belli bir katkısının olduğu söylenebilir.

İnsanın kendi zaman ve mekânına daldırılmışlığını, tarihselliğini bu denli ciddiye alması Yeni Tarihselciliği, okurun tarih üstüne çıkarak evrensel saptamalarda bulunmasına olduğu gibi, metinlere belli bir yöntemle yaklaşma düşüncesine de mesafeli yaklaşmasına neden olur. Kotan'ın da öne çıkardığı üzere, insan zihninin sonsuz olanakları nedeniyle tarihsel olay biriciktir, tekrarlanamaz, bu yüzden yöntem bilimin kabına sığmaz. ${ }^{40}$ Sistematikleştirmeye karşı bir duruş takınan Yeni Tarihselciler, kendi zamanlarından ve mekânlarından ve ilgilendikleri belli nesnelerden bağımsız bir sistem kurma imkânından şüphe ${ }^{41}$ duyduklarını dile getirirler. Metinler karşısında tekrarlanabilen yöntembilimsel talimatlara sahip olmadıkları için kendilerini "olasılıklar tarihi" olarak adlandırırlar. Bu olasılıklar tarihinde her Yeni Tarihselci eleştirmen okuma tecrübesinin zamansallığını tatmak durumunda kalır.

Yeni Tarihselciliğin anlamanın zamansallığg ve tarihselliğine açmış olduğu yer üzerine konuşurken, Greenblatt'ın edebi metin ve edebi metnin açığa çıktığı bağlam arasındaki etkileşimi vurgulayan "toplumsal enerjinin dolaşımı" 42 ifadesine değinmek de yerinde olacaktır. Bir taraftan toplumsal enerjinin dolaşımı söylemi etrafında edebi eserler, açığa çıkmış olduğu bağlamın çeşitli unsurları ile biçimlendirilirken diğger taraftan da kendilerini biçimlendiren bu tarihsel, kültürel, toplumsal unsurları biçimlendirirler. Toplumsal enerjinin etkisi altında üretilip dolaşıma çıkan eser, bu sefer de toplumu etkileyen bir enerjinin kendisi haline dönüşür. Bu durum temelde insanın içine doğduğu mevcut ortama pasif bir bağımlılığının dışına çıkarak onu aktif biçimde değiştirme imkânına sahip oluşuyla ilgilidir.

40 Şevket Kotan, Kuran ve Tarihselcilik, 181.

41 Gallagher ve Greenblatt, "Yeni Tarihselciliği Uygulamak", 21.

42 Stephen Greenblatt, Shakespearean Negotiations, The Circulation of Social Energy in Renaissance England (Berkeley: University of California Press, 1988), 1. 
Okumanın Tarihsellioği ve Alımlama Estetiŏi ile...

Diğer taraftan Yeni Tarihselcilik, edebi metin ve tarih arasındaki karşılıklı etkileşime özel bir önem atfederken, okumanın asıl tarihselliğini tesis edecek edebi eser ve okur arasındaki karşılıklı etkileşime gereken itinayı gösterememiş gibidir. Bu anlamda Yeni Tarihselcilerin yaklaşımlarında uzun uzadıya dolaylı şekillerle tartışmaya açtıkları "metnin tarihselliği, tarihin metinselliği" kavramları dışında daha az ilgilendikleri şeyin, edebiyat eseri karşısındaki estetik tecrübeleri bağlamında "okurun tarihselliği" oluşu dikkat çeker. Okuma tecrübesinin her okurun tarihselliğinde vuku bulan tekrarlanamazlığ1 ve özgünlüğü üzerine yoğunlaşmak ve metnin tarihselliğine biraz da bu açıdan yaklaşmak, Yeni Tarihselciliğin iktidar ilişkileri bağlamında metnin nerede durduğunu ortaya çıkarıp alternatif bir karşı tarih yazmak sorumluluğu yanında önemsizleşir. Aslında bu anlamda Yeni Tarihselcilik, sadece okurun tarihselliği üzerine yoğunlaşmada değil, metnin tarihselliğine farklı boyutlarıyla bakamama sınırlılığına da sahiptir.

Kendilerinden farklı olarak kültürel metinselciliklerinde tarihselci bir soy olmadıklarını vurguladıkları yapısökümcülere yönelttikleri eleştiri bu noktada bize bir şeyler söyleyebilir: "Onlara göre yazılı dil, içinde anlam üretme sorunları tezahür ettiği dizisel biçimdir ve bir kültür, anlamlı göstergeleri doğal olarak girift, çelişik ve karar verilemez olduğundan dolayı 'metinsel'dir denebilir. Dolayısıyla yapısökümcü edebiyat çözümlemeleri sürekli tüm bilinmezlerin kaynağı ve yapısı olarak metinselliğe döner." ${ }^{43}$ Bu eleştiri karşısında, ilk elden akla gelen sorun, edebi metni bilinmezlerin kaynağı olarak görmenin, gerçekten tarihsel bir soya sahip olmaya engel olup olamayacağı sorusudur. Zira tek boyutu bu olmasa da okuma tecrübesinin azami derecede belirlenemezlik içermesinde bu anlamda tarihselliğinde, edebi metnin belirlenemez, tamamlanamaz linguistik düzeylere sahip oluşunun göz ardı edilemez bir etkisi bulunur. Yöntem fikrine karşı olmalarına rağmen ‘Işıldayan Detay Yöntemi'ni benimseyen ve ayrıntının gerçekten de ışıldadığına inanan Yeni Tarihselcilerin metnin tamamlanamaz, belirlenemezliğinin sunmuş olduğu 1şıltıları, fosforu görmezden gelmeleri bu yaklaşımın garip bir ayrıntısıdır. Diğer taraftan indirgemeci tavırlarını eleştirdikleri yapısökümcü edebiyat çözümlemeleri, kendi indirgemeci uygulamalar derlemelerine de ışık tutulmasını sağlar.

43 Gallagher ve Greenblatt, "Yeni Tarihselciliği Uygulamak”, 31. 
Yapısökümcülerin tüm bilinmezlerin kaynağı olarak metinselliğe dönmesi gibi, Yeni Tarihselciler de yalnızca iktidar ilişkilerinin açığa çıkarılmasının bir kaynağı olarak metinselliğe döner. Zira Oppermann'ın öne çıkardığı gibi Greenblatt, Rönesans dönemi tiyatro oyunlarını Avrupa güçlerinin korkunç koloni politikaları etrafında yorumlar ve ezilen, baskılanan ötekilerin tarihine dikkat çeker. ${ }^{44}$ Yine Gecikli'nin dile getirdiği üzere, Yeni Tarihselciler bu halleriyle ötekilerin ve marjinallerin tarihiyle ilgilenmeyi bilinçli olarak tercih ederek, köleler, eşcinseller, suçlular, kadınlar, deliler ve temel haklardan mahrum bırakılan bütün görmezden gelinenlerin öykülerini anlatır. ${ }^{45}$ Ancak görünen o ki, Yeni Tarihselcilik bir taraftan göz ardı edilenlerin tarihine odaklanarak kendisini yapılandırırken, öte taraftan bazı boyutlarıyla okumanın, anlamanın tarihselliğini göz ardı etme sorununu üretmeye başlamıştır. Yine de bütün bunlara rağmen Uslu'nun vurguladığg üzere, Yeni Tarihselci yaklaşımın edebiyat eleştirisinde büyü bozumunu ${ }^{46}$ kurumsallaştırma noktasında sunmuş olduğu katkı ve zenginlik oldukça açıktır.

\section{Sonuç}

Yazı boyunca tartışılmaya çalışılan sorunlar ne alımlama estetiğinin ne de Yeni Tarihselciliğin edebi metnin yorumlanmasında gerekli olan tarihsel bilincin varlığına cömertçe açtığı yeri görmezden gelmemize engel değildir. Alımlama Estetiği ve Yeni Tarihselcilik şüphesiz Yeni Eleştiri sonrası kaybolan tarihsel bilince dönüş çabaları arasında anlamlı bir noktada durur. Her şeyden evvel tarihsel bir eylem olarak her ikisi de eleştiri tarihi denen anlam geleneğinin sürekliliğine önemli birer katkıdır. Dahası edebiyat ve tarih arasındaki ilişki belirlenirken kendilerine dayandırılan klasik tarih ve tarihselcilik anlayışlarının dışına çıkar ve onlara eleştirel bir gözle bakılmasını sağlarlar. Her iki yaklaşım da öne çıkarmış olduğu çeşitli kavramlar ve bu kavramları büründürdükleri farklı tonlamalarla, oku-

44

Oppermann, Postmodern Tarih Kurami: Tarihyazımı, Yeni Tarihselcilik ve Roman, 1617.

Gecikli, "Yeni Tarihselcilik", 279.

Mehmet Fatih Uslu, "Greenblatt'1n Yeni Tarihselci Eleştirisi”, Kritik Dergisi 1 (Mart, 2008): 18. Yeni Tarihselcilik bir taraftan belli bir büyü bozumunu kurumsallaştırırken bir taraftan da Greenblatt'ın Shakespearean Negotiations adlı ünlü çalışmasının hemen girişinde yeni tarihselci serüvenini “ölülerle konuşma arzusuyla yola koyuldum" şeklinde dile getirmesi ve edebiyat hocalarının "maaş alan, orta sınıfa mensup şamanlar" olarak tanımlaması itibarıyla edebi metnin yorumlanmasında ayrı bir büyüsel ortamın oluşmasına da sebebiyet verir. 
run kendisini tarih içinde buluvermesi, tecrübenin zamansallığı, insanın ve edebi metnin tamamlanamazlığı gibi noktalarda okumanın tarihselliğine farklı boyutlarda yer açar. Alımlama Estetiğinin "okurun tarihselliği", Yeni Tarihselciliğin ise "metnin tarihselliği, tarihin metinselliği" vurgusuyla edebi eserlerin yorumlanmasında tarihsel olanın göz ardı edilemezliği üzerinde durur. Ancak her iki yaklaşımda da edebi metinleri anlamanın tarihselliğinin, okurun yahut metnin tarihselliği üzerinden şekillendirilmesinin ağır bastığı görülür. Alımlama Estetiğinin daha ziyade okurun metni şekillendiren tarihselliğini, Yeni Tarihselciliğin ise metnin okuru şekillendiren tarihselliğini ön plana çıkaran tutumları, edebi metinleri anlamanın çift yönlü tarihselliğini iki karşı uçtan eksik bırakır. Ayrıca, edebi eserin yorumlanması ve tarihsellik arasında ilişki kuran bu iki yaklaşımın, zaman zaman edebi metnin bizatihi varoluşunu ve kurgusal varlık olma talebini tehlikeye attığı söylenebilir. Yine de edebiyatın tarihle, tarihselle kuracağı anlamlı ilişkinin temelde anlamanın, okumanın tarihselliği düşüncesi üzerinden kurulabileceği noktasında diğer edebiyat teorilerine göre hayli geniş bir kavramsal birikim ve düşünce dünyasına sahiplerdir. Bu haliyle edebi eserin yorumlanması hususunda tarihi kendisine dönülebilir bir geçmiş olarak konumlandıran tarihselci edebiyat teorisinin klasik tarih ve tarihselcilik düşüncesinin de uzağındadırlar.

\section{Kaynakça}

Aksoy, Nazan. "Yeni Eleştiri", Eleştiri ve Eleştiri Kuramı Üstüne Söylemler. Haz. Mehmet Rifat, 15-28. İstanbul: Düzlem Yayınları, 1996.

Culler, Jonathan. "Yorumun Ötesinde". Çev. Ahmet Kocaman, Kuram Dergisi 5 (1994): 62-68.

Eagleton, Terry. Edebiyat Kuramı: Giriş. Çev. Tuncay Birkan. İstanbul: Ayrintı Yayınları, 2011.

Gadamer, Hans-Georg. Hakikat ve Yöntem. II. Çev. Hüsamettin Arslan ve İsmail Yavuzcan. İstanbul: Paradigma Yayınları, 2009.

, "Hermeneutik", Hermeneutik Üzerine Yazılar. Der. ve çev. Doğan Özlem, 13-32. İstanbul: İnkılap, 2003.

Gallagher, Catherine ve Greenblatt, Stephen. "Yeni Tarihselciliği Uygulamak". Çev. Berat Açıl. Kritik Dergisi 1 (Mart, 2008): 20-34.

Practicing New Historicism. Chicago: The University of Chicago Press, 2000.

Gecikli, Kubilay. "Yeni Tarihselcilik”, Çă̆daş Edebiyatın Kuramsal Seyri. Ed. Aytaç Ören, Mümin Hakkığlu. Konya: Çizgi Kitabevi, 2019, 249289. 
Greenblatt, Stephen. Shakespearean Negotiations, The Circulation of Social Energy in Renaissance England. Berkeley: University of California Press, 1988.

Iser, Wolfgang. The Act of Reading: A Theory of Aesthetic Response. Baltimore, London: John Hopkins University Press, 1978.

Jauss, Hans Robert, "Bilimsel Bir Yazın Tarihinin Çağırışı”. Çev. Tevfik Turan. Bă̆lam Dergisi 2 (İstanbul, 1980): 89-122.

"Literary History as a Challenge to Literary Theory", Toward on an Aesthetic of Reception. Trans. Timothy Bahti. Minneapolis: The University of Minnesota Press, 1982.

Kayalı, Kurtuluş. "Siyaset Kıskacından Biçimcilik Kıskacına Tarihsel ve Sosyolojik Damarını Kaybetme Tehlikesi Sınırında Gezinen Türk Edebiyatı". Dogŭ Batı Dergisi 22 (2003): 79-90.

Kotan, Şevket. Kuran ve Tarihselcilik. İstanbul: Beyan Yayınları, 2015.

Oppermann, Serpil. Postmodern Tarih Kurami: Tarihyazımı, Yeni Tarihselcilik ve Roman. Ankara: Phoenix, 2006.

Palmer, Richard E. Hermenötik. Çev. Ibrahim Görener. İstanbul: Ağaç Kitapevi, 2008.

Ricoeur, Paul. Zaman ve Anlatı: Dört, Anlatılan (Öykülenen) Zaman. Çev. Umut Öksüzan ve Atakan Altınörs. İstanbul: Yapı Kredi Yayınları, 2013.

Tatar, Burhanettin. Felsefi Hermenötik ve Yazarm Niyeti: Gadamer vs. Hirsch. İstanbul: Vadi Yayınları, 2016. "İkinci Baskıya Giriş", Şevket Kotan, Kuran ve Tarihselcilik. 13-19. İstanbul: Beyan Yayınları, 2015.

3 Derste Hermenötik. İstanbul: Vadi Yayınları, 2016.

Uslu, Mehmet Fatih. Greenblatt'ın Yeni Tarihselci Eleştirisi. Kritik Dergisi 1 (2008): 1-19.

Uysal, Zeynep, Edebiyatın Omzundaki Melek, Edebiyatın Tarihle İlişkisi Üzerine Yazılar. Haz. Zeynep Uysal. İstanbul: İletişim, 2011.

Wimsatt, William Kurtz ve Beardsley, Monroe Curtis. "The Intentional Fallacy", The Verbal Icon: Studies in the Meaning of Poetry. 3-20. Kentucky: University of Kentucky Press, 1954.

"The Affective Fallacy", The Verbal Icon: Studies in the Meaning of Poetry. 21-40. Kentucky: University of Kentucky Press, 1954. 